\title{
PERAMALAN JUMLAH WISATAWAN AUSTRALIA YANG BERKUNJUNG KE BALI MENGGUNAKAN MULTIVARIAT FUZZY TIME SERIES
}

\author{
I Made Candra Satria ${ }^{\S 1}$, I Komang Gde Sukarsa ${ }^{2}$, Ketut Jayanegara ${ }^{3}$ \\ ${ }^{1}$ Jurusan Matematika, Fakultas MIPA - Universitas Udayana [Email: candrasatria.19@gmail.com] \\ ${ }^{2}$ Jurusan Matematika, Fakultas MIPA - Universitas Udayana [Email: sukarsakomang@yahoo.com] \\ ${ }^{3}$ Jurusan Matematika, Fakultas MIPA - Universitas Udayana [Email: ketut_jayanegara@yahoo.com] \\ ${ }^{\S}$ Corresponding Author
}

\begin{abstract}
The aim of this paper is to forecast the numbers of Australian tourist to Bali using multivariate fuzzy time series method (MFTS). MFTS method is development from fuzzy time series (FTS). The defferent betwen FTS and MFTS method is showed by factor in used. In FTS method using one factor, but in MFTS method using more than one factor. In this peper there was three factor used in this research, it was number of Australian tourist, Indonesian Inflation, and change rate of AUD to IDR. At the beginning, the speed of each factor was calculated. For each factor given weight, 0,999 for numbers of Australian tourist, -0,90 for Indonesian inflation, and 0,21 for change rate of AUD to IDR. The result showed that Australian tourist at July 2014 would visit Bali as much 91.056 tourist, with average error rate $6.87 \%$.
\end{abstract}

Keywords: Multivariate Fuzzy Time Series Method, Inflation of Indonesian, Change Rate of AUD to IDR, Australian tourist.

\section{PENDAHULUAN}

Bali merupakan salah satu destinasi wisata yang banyak diminati oleh wisatawan asing maupun domestik. Pada tahun 2013 jumlah wisatawan asing yang berkunjung ke Bali didominasi oleh wisatawan Australia yang mencapai 826.385 jiwa (Dispar Provinsi Bali, 2014 [1]). Beberapa faktor yang memengaruhi wisatawan berkunjung ke suatu wilayah negara, seperti nilai tukar mata uang, inflasi disuatu wilayah kunjungan wisatawan, dan letak geografis suatu wiyalah negara.

Semakin besar nilai tukar mata uang suatu negara terhadap rupiah, maka kecenderungan warga negara tersebut untuk berkunjung ke Indonesia semakin besar. Letak geografis atau jarak juga menjadi salah satu faktor yang menentukan jumlah wisatawan asing ke Bali. Sebagai contoh, wisatawan dari Australia mungkin lebih tertarik untuk berkunjung ke Bali karena jarak kedua negara dekat.
Jumlah wisatawan yang berkunjung ke Bali pada suatu periode tertentu dapat diramalkan secara matematis. Salah satu metode yang dapat digunakan adalah multivariat fuzzy time series (MFTS). Metode MFTS adalah metode peramalan data yang menggunakan prinsip-prinsip fuzzy sebagai dasarnya. Sistem peramalan dengan MFTS menangkap pola dari data yang telah lalu kemudian digunakan untuk memproyeksikan data yang akan datang hanya menggunakan lebih dari satu variabel ( $\mathrm{m}$-factor, $\mathrm{k}$-order) $\mathrm{m} \geq$ 2.

Beberapa penelitian tentang peramalan telah dilakukan oleh peneliti, diantaranya tentang Peramalan Produk Domestik Regional Bruto (PDRB) Propinsi Bali dengan Menggunakan Metode Fuzzy Time Series (Wanayasa [2]), penelitian tersebut hanya menggunakan satu faktor yaitu Produk Domestik Regional Bruto (PDRB) Propinsi Bali. Selanjutnya penelitian tentang Peramalan 
Tingkat Suku Bunga Sertifikat Bank Indonesia Berdasarkan Data Fuzzy Time Series Multivariat (Abadi [3]), penelitian ini menggunakan satu faktor utama yaitu tingkat suku bunga SBI dan enam faktor pendukung yaitu tingkat suku bunga deposito, nilai tukar rupiah terhadap dollar Amerika, jumlah deposito, tingkat inflasi dan jumlah uang beredar. Penelitian tentang Multivariate High Order Fuzzy Time Series Forecasting for Car Road Accidents (Jilani \& Ardil [4]), penelitian ini menggunakan satu faktor utama yaitu angka kematian kecelakaan dan empat faktor pendukung yaitu kematian setelah cidera parah, kematian setelah 30 hari, cidera parah, cidera ringan.

Penelitian yang penulis teliti berbeda dengan penelitian yang telah dilakukan sebelumnya, pada penelitian ini penulis mengitung hasil peramalan jumlah kunjungan wisatawan Australia ke Bali menggunakan FTS dan MFTS. Untuk metode FTS hanya digunakan satu faktor yaitu jumlah kunjungan wisatawan Australia ke Bali, sedeangkan perhitungan MFTS menggunakan satu faktor utama yaitu jumlah kunjungan wisatawan Australia ke Bali dan faktor pendukung yaitu kurs Australia terhadap Indonesia dan Inflasi Indonesia.

Tujuan adalah mengetahui komparasi kinerja FTS dengan MFTS dalam memodelkan jumlah wisatawan Australia yang berkunjung ke Bali dan mengetahui prediksi jumlah wisatawan Australia yang berkunjung ke Bali pada satu bulan berikutnya.

\section{METODE PENELITIAN}

\section{Fuzzy Time Series (FTS) dan Multivariat Fuzzy Time Series (MFTS)}

Metode fuzzy time series merupakan metode peramalan dimana data masa lalu digunakan untuk meramalkan data yang terjadi dimasa yang akan datang (Makridakis, Wheelwright, \& McGee [5]). Data time series sangat berguna dalam pengambilan keputusan untuk memperkirakan kejadian yang terjadi di masa yang akan datang. Model time series diyakini memiliki pola yang berulang dimana periode pada masa lampau akan terulang kembali pada masa sekarang.

Sistem peramalan dengan menggunakan fuzzy time series menangkap pola dari data yang telah terjadi sebelumnya kemudian digunakan untuk memproyeksikan data yang akan datang. Pada fuzzy time series, proses peramalan data tidak membutuhkan suatu sistem pembelajaran yang rumit seperti pada algoritma genetika dan jaringan syaraf sehingga mudah untuk dikembangkan.

Perbedaan utama antara FTS dan MFTS teletak pada faktor yang digunakan dalam pembentukan model peramalan. Pada FTS faktor yang dipertimbangkan hanya satu, sedangkan MFTS mempertimbangkan lebih dari satu faktor, satu sebagai faktor utama dan lainnya merupakan faktor pendukung. Inti dari MFTS adalah mendefinisikan semesta pembicaraan $U$ kemudian jika diberikan himpunan semesta $Y(t) \subset R, t=0,1,2, \ldots$, dengan $f_{i}(t)(i=1,2,3, \ldots)$ adalah himpunan fuzzy yang didefinisikan pada $Y(t)$ dan jika $F(t)$ adalah koleksi dari $f_{i}(t)$, maka $F(t)$ desebut FTS pada $Y(t)$. Jika FTS $F(t)$ dapat dipandang sebagai variable linguistik dengan $f_{i}(t)$ sebagai nilai linguistik yang mungkin dari $F(t)$. Nilai dari $F(t)$ dapat berbeda-beda tergantung pada waktu $t$ sehingga $F(t)$ merupakan fungsi $t$. Jika Suatu fungsi time series $F(t)$ yang dipengaruhi oleh faktor lainya dapat dinyatakan dengan suatu relasi fuzzy

$[F(t-n) \ldots, F(t-3), F(t-2), F(t-1)] \rightarrow F_{1}(t)$

Persamaan $F_{1}(t)$ menunjukan bahwa $F_{1}(t)$ diperoleh dengan mempertimbangkan $F(t-$ 1), $F(t-2), \ldots, F(t-n)$ dengan kata lain, hasil ramalan ke-t diperoleh dari meninjau data yang sebelumnya. Bentuk model FTS digunakan fungsi segitiga untuk diperoleh laju defuzzyfikasi. Berikut adalah fungsi segitiga yang digunakan untuk menghitung laju defuzzyfikasi 


$$
t_{j}=\left\{\begin{array}{c}
\frac{1+0,5}{\frac{1}{a_{1}}+\frac{0,5}{a_{2}}} \quad, \text { jika } j=1 \\
\frac{0,5+1+0,5}{0,5} \frac{1}{a_{j-1}+\frac{0,5}{a_{j+1}}} \quad, \text { jika } 2 \leq j \leq n-1 \\
\frac{0,5+1}{\frac{0,5}{a_{n-1}}+\frac{1}{a_{n}}} \quad, \text { jika } j=n
\end{array}\right.
$$

Pengembangan dari FTS dengan penambahan faktor-faktor pendukung $F_{1}, F_{2}, F_{3}, \ldots, F_{m}$ dimana $F_{1}$ merupakan faktor utama dan $F_{2}, F_{3}, \ldots, F_{m}$ sebagai faktor pendukung

$$
\begin{aligned}
& \quad\left\{F_{1}(t-n), F_{2}(t-n), F_{3}(t-n), \ldots, F_{m}(t-n)\right\}, \ldots, \\
& \left\{F_{1}(t-3), F_{2}(t-3), F_{3}(t-3), \ldots, F_{m}(t-3)\right\}, \ldots, \\
& \left\{F_{1}(t-2), F_{2}(t-2), F_{3}(t-2), \ldots, F_{m}(t-2)\right\}, \ldots \\
& \left.\left\{F_{1}(t-1), F_{2}(t-1), F_{3}(t-1), \ldots, F_{m}(t-1)\right\}\right] \\
& \rightarrow F_{1}(t), F_{2}(t), F_{3}(t), \ldots, F_{m}(t)
\end{aligned}
$$

Persamaan tersebut disebut sebagai relasi MFTS. Bentuk model MFTS digunakan fungsi segitiga untuk diperoleh laju defuzzyfikasi untuk tiap-tiap faktor, kemudian dari laju defuzzyfikasi tersebut diberikan masingmasing bobot, dimana bobot diperoleh dari bantuan softwere problem solving pada microsoft excel. Berikut ini adalah model dari MFTS:

$\alpha_{t}^{*}=\frac{1}{\omega} \cdot\left[\omega_{1} \cdot \alpha_{(1,(t-1))}+\omega_{2} \cdot \alpha_{(2,(t-1))}+\omega_{3} \cdot \alpha_{(3,(t-1))}\right.$

$\left.\cdots+\omega_{m} \cdot \alpha_{(m,(t-1))}\right]$

Dengan

$\alpha_{t}^{*}=$ Laju perubahan kunjungan wisatawan hasil peramalan

$\omega=$ Total bobot

$\omega_{1}=$ Bobot faktor utama

$\omega_{2}, \omega_{3}, \omega_{m}=$ Bobot faktor pendukung

$\alpha_{(1,(t-1))}=$ Laju kunjungan defuzzyfikasi wisatawan pada bulan sebelumnya

$\alpha_{(2,(t-1))}=$ Laju perubahan defuzzyfikasi

inflasi Indonesia pada bulan

sebelumnya $\alpha_{(3,(t-1))}=$ Laju perubahan defuzzyfikasi kurs

\section{Analisis Fuzzy Time Series}

Langkah-langkah dasar yang digunakan dalam metode fuzzy time series untuk peramalan (Stevenson \& Porter [6]), antara lain:

1. Mendefinisikan himpunan semesta $U=\left[D_{\min }, D_{\max }\right] \quad$ dan membaginya menjadi interval $u_{1}, u_{2}, \ldots, u_{n}$ dengan panjang yang sama.

Dalam penentuan jumlah kelas interval digunakan rumus (Sturges [9]), yaitu:

$K=1+3.322 \log (N)$

dengan:

$K=$ Jumlah Kelas Interval

$N=$ Jumlah Data Observasi

2. Mendefinisikan masing-masing himpunan fuzzy menurut interval yang sudah dibagi dan memfuzzykannya. Dimana himpunan fuzzy dinotasikan sebagai nilai linguistik dari data aktual yang diwakili oleh himpunan fuzzy.

3. Melakukan defuzzyfikasi data fuzzy dengan menggunakan pendekatan yang dianjurkan oleh Stevenson \& Porter [6] melalui persamaan (2.7) Dengan $a_{j-1}, a_{j}, a_{j+1}$ merupakan nilai tengah dari masing-masing interval fuzzy $F_{j-1}, F_{j}, F_{j+1}$ dan $t_{j}$ adalah hasil prediksi dari perubahan persentase )data dimana perubahan persentase peramalan tahun sebelumnya dapat digunakan untuk menentukan perubahan persentase tahun berikutnya..

4. Mengubah persentase hasil peramalan ke dalam bentuk angka kembali sehingga dapat ditentukan nilai Average Forcasting Error Rate (AFER).

$$
A F E R=\frac{\sum_{a=1}^{n} \frac{\left|X_{a}-F_{a}\right|}{X_{a}}}{n}(100 \%)
$$




\section{Analisis Multivariat Fuzzy Time Series}

Langkah-langkah dasar yang digunakan dalam metode MFTS untuk peramalan, antara lain (Jilani \& Ardil [4]):

1. Definisikan himpunan semesta $U=\left[D_{\min }, D_{\max }\right]$ dari faktor utama dan faktor pendukung kemudian membaginya menjadi interval $u_{1}, u_{2}, \ldots, u_{n}$ dengan panjang yang sama. Dalam penentuan jumlah kelas interval digunakan persamaan Sturges. Lalu tentukan frekuensi dari masing-masing selang interval.

2. Mendefinisikan masing-masing himpunan fuzzy $A_{i}$ sebagai faktor utama dan $B_{i}$ sebagai faktor pendukung, menurut interval yang sudah dibagi dan memfuzzykannya.

3. Tentukan m-faktor orde ke-k dari hubungan fuzzy logic berdasarkan faktor utama dan pendukung yang telah di fuzzyfikasi. Kemudian bentuk m-faktor orde ke-k menjadi fuzzy logic reletionships.

$$
\begin{aligned}
& \left(X_{j-k} ; Y_{2, j-k} Y_{m-1, j-k}\right), \ldots,\left(X_{j-2} ; Y_{2, j-2}, \ldots, Y_{m-1, j-2}\right), \\
& \left(X_{j-1} ; Y_{1, j-1}, Y_{2, j-1, \ldots,}, Y_{m-1, j-1}\right), \rightarrow X_{j}
\end{aligned}
$$

dengan $j>k, X_{j-k}$ menunjukan bahwa langkah ke-k dependence dari nilai ke-j dari faktor utama $X_{j}, Y_{i, j-k}, i=1, \ldots, m-1$, $j=1, \ldots, k$ kemudian bagi hubungan fuzzy logical yang diturunkan menjadi kelompok - kelompok fuzzy logical berdasarkan kondisi saat ini dari hubungan - hubungan fuzzy logical. Faktor pendukung berfungsi sebagai komponen pendukung vektor ruang berdimensi $m$.

4. Melakukan defuzzyfikasi data fuzzy dengan menggunakan pendekatan yang dianjurkan oleh Stevenson \& Porter [6] melalui persamaan (2). Dengan $a_{l-1}, a_{l}$ dan $a_{l+1}$ adalah titik tengah dari interval $F_{j-1}, F_{j}, F_{j+1}$ berturut-turut dan $t_{j}$ adalah hasil prediksi dari perubahan persentase data dimana perubahan persentase peramalan tahun sebelumnya dapat digunakan untuk menentukan perubahan persentase tahun berikutnya.

5. Mencari laju perubahan kunjungan wisatawan Australia yang dipengaruhi faktor utama dan faktor pendukung dengan mengunakan persama segitiga.

6. Mengubah hasil peramalan sesuai laju yang diperoleh ke dalam bentuk angka, sehingga dapat ditentukan nilai Average Forcasting Error Rate (AFER)

\section{HASIL DAN PEMBAHASAN}

Pada peramalan Jumlah kunjungan wisatawan Australia dengan metode fuzzy time series, tahap-tahap yang dilakukan yaitu mengubah data jumlah kunjungan wisatawan Australia menjadi data laju pertumbuhan. Kemudian menentukan nilai $\mathrm{D}_{\text {min }}$ dan $\mathrm{D}_{\max }$ dari data jumlah kunjungan wisatawan Australia yang telah diubah menjadi data laju pertumbuhan dimana nilai dari $\mathrm{D}_{\min }$ adalah $27,72 \%$ dan $D_{\max }$ adalah $30,96 \%$ dengan pendekatan $d_{1}$ dan $d_{2}$ maka $\mathrm{D}_{\min }=-28,00 \%$ dan $\mathrm{D}_{\max }=31,00 \%$. Lebar interval $U$ adalah $8,43 \%$. Kemudian membagi himpunan semesta $U$ menjadi 7 interval dengan panjang yang sama.

Kemudian pada tahap berikutnya dibentuk himpunan fuzzy serta penentuan nilai linguistik dari data laju kunjungan wisatawan yang diperoleh dari tahap sebelumnya. Hasil pembentukan himpunan fuzzy dan penentuan nilai linguistik dapat dilihat pada Tabel 1 .

Tabel 1. Interval Fuzzy dan Nilai Lingustik Berdasarkan Distribusi Perubahan Persentase

\begin{tabular}{|c|c|c|c|c|c|}
\hline No & Interval & $\begin{array}{c}\text { Batas } \\
\text { Kiri }\end{array}$ & $\begin{array}{c}\text { Nilai } \\
\text { Tengah }\end{array}$ & $\begin{array}{c}\text { Batas } \\
\text { Kanan }\end{array}$ & $\begin{array}{c}\text { Nilai } \\
\text { Linguistik }\end{array}$ \\
\hline 1 & $A_{1}$ & $-28,00 \%$ & $-23,79 \%$ & $-19,57 \%$ & $a_{1}$ \\
\hline 2 & $A_{2}$ & $-19,57 \%$ & $-15,36 \%$ & $-11,14 \%$ & $a_{2}$ \\
\hline 3 & $A_{3}$ & $-11,14 \%$ & $-6,93 \%$ & $-2,71 \%$ & $a_{3}$ \\
\hline 4 & $A_{4}$ & $-2,71 \%$ & $1,50 \%$ & $5,71 \%$ & $a_{4}$ \\
\hline 5 & $A_{5}$ & $5,71 \%$ & $9,93 \%$ & $14,14 \%$ & $a_{5}$ \\
\hline 6 & $A_{6}$ & $14,14 \%$ & $18,36 \%$ & $22,57 \%$ & $a_{6}$ \\
\hline 7 & $A_{7}$ & $22,57 \%$ & $26,79 \%$ & $31,00 \%$ & $a_{7}$ \\
\hline
\end{tabular}


Setelah pembagian interval dilakukan penamaan masing-masing interval dengan menggunakan variabel fuzzy yang biasa disebut variabel $A_{1}$ sampai $A_{7}$ dan nilai tengah merupakan nilai tengah dari jarak masingmasing interval dan diberi nama nilai linguistik $a_{1}$ sampai $a_{7}$. Nilai tengah ini akan digunakan pada tahap defuzzyfikasi. Tahap selanjutnya yaitu menentukan fuzzy set masing-masing data persentase yaitu dengan cara memasukan data persentase ke dalam interval yang sudah ditentukan sebelumnya.

Langkah selanjutnya adalah menentukan Fuzzy Logic Relationship Group (FLRG) dimana FLRG terbentuk dari Left-hand Side (LHS) dan Right-hand Side (RHS) dari fuzzy set yang sudah ditentukan pada tabel 1. Lefthand Side (LHS) merupakan fuzzy set yang berada pada sisi kiri himpunan fuzzy sedangkan Right-hand Side (RHS) merupakan fuzzy set yang berada pada sisi kanan himpunan fuzzy. Pada penentuan FLRG ini, yang menjadi LHS adalah semua fuzzy set yang urutannya sama dengan urutan fuzzy set yang telah ditentukan sebelumnya sedangkan yang menjadi RHS adalah fuzzy set pada LHS yang kedua. FLRG dapat dinotasikan dengan Daftar kemunculan FLRG dari periode Juli 2009 - Juni 2014 disajikan pada tabel 2.

Tabel 2. Distribusi FLRG untuk Jumlah Kunjungan Wisatawan Australia

\begin{tabular}{|c|c|c|c|}
\hline $\begin{array}{c}\text { Distribusi } \\
\text { FLRG }\end{array}$ & Frekuensi & $\begin{array}{c}\text { Distribusi } \\
\text { FLRG }\end{array}$ & Frekuensi \\
\hline$A_{1}=>A_{5}$ & 1 & $A_{4}=>A_{3}$ & 5 \\
\hline$A_{1}=>A_{6}$ & 2 & $A_{4}=>A_{5}$ & 2 \\
\hline$A_{1}=>A_{7}$ & 1 & $A_{4}=>A_{6}$ & 2 \\
\hline$A_{2}=>A_{3}$ & 1 & $A_{5}=>A_{3}$ & 1 \\
\hline$A_{2}=>A_{4}$ & 1 & $A_{5}=>A_{4}$ & 2 \\
\hline$A_{2}=>A_{6}$ & 4 & $A_{5}=>A_{5}$ & 3 \\
\hline$A_{2}=>A_{7}$ & 1 & $A_{6}=>A_{2}$ & 2 \\
\hline$A_{3}=>A_{1}$ & 3 & $A_{6}=>A_{3}$ & 5 \\
\hline$A_{3}=>A_{2}$ & 1 & $A_{6}=>A_{4}$ & 1 \\
\hline$A_{3}=>A_{3}$ & 1 & $A_{6}=>A_{7}$ & 3 \\
\hline$A_{3}=>A_{4}$ & 4 & $A_{7}=>A_{1}$ & 1 \\
\hline$A_{3}=>A_{5}$ & 1 & $A_{7}=>A_{2}$ & 2 \\
\hline$A_{3}=>A_{6}$ & 2 & $A_{7}=>A_{4}$ & 2 \\
\hline$A_{3}=>A_{7}$ & 1 & $A_{7}=>A_{6}$ & 1 \\
\hline$A_{4}=>A_{2}$ & 2 & \multicolumn{2}{|l}{} \\
\cline { 1 - 2 } & & &
\end{tabular}

FLRG akan digunakan untuk peramalan outsample. Peluang kemunculan nilai fuzzy merupakan sebagai patokan untuk peramalan bulan berikutunya atau peramalan pada Juli 2014.

Tahap berikutnya adalah defuzzyfikasi data dengan menggunakan pendekatan yang dianjurkan oleh (Stevenson \&Porter [6]) yang menghasilkan peramalan perubahan persentase laju pertumbuhan jumlah kunjungan wisatawan Australia dari bulan ke bulan berikutnya. Setelah persentase laju pertumbuhan jumlah kunjungan wisatawan Australia diketahui maka dengan menggunakan persentase perubahan peramalan bulan sebelumnya, dapat ditentukan persentase perubahan jumlah kunjunan wisatawan Australia pada bulan berikutnya.

Pada data terakhir yaitu data pada Juni 2014 mempunyai nilai perubahan persentase sebesar $8,12 \%$ dimana data tersebut masuk ke dalam fuzzy set $A_{5}$. Pada FLRG $A_{5}$ sebagai LHS yang memiliki RHS $A_{3}, A_{4}$, dan $A_{5}$. Peluang RHS $A_{5}$ paling sering muncul dengan frekuensi 3, jadi yang digunakan untuk meramalkan bulan Juli 2014 adalah fuzzy set $A_{5}$. Untuk mencari nilai perubahan persentase pada Juli 2014, maka kita akan menggunakan nilai min $1,50 \%$, middle $9,93 \%$, dan $\max$ $18,36 \%$, selanjutnya menggunakan tahap defuzzyfikasi data dengan menggunakan persamaan segitiga, akan dicari nilai perubahan persentase untuk bulan Juli 2014. Nilai persentase perubahan bulan juli 2014 sebesar $3,43 \%$, nilai persentase tersebut akan dikembalikan menjadi data aktual dengan rumus

$$
\begin{aligned}
& \text { data aktual }=\left(\begin{array}{c}
\% \text { data perubahan } \\
\times \text { data sebelumnya }
\end{array}\right) \\
& \quad+\text { data sebelumnya }
\end{aligned}
$$

Jadi hasil peramalan jumlah kunjungan wisatawan Australia menggunakan FTS sebesar 90.033 jiwa

\section{Peramalan Menggunakan MFTS}

Langkah peramalan pada MFTS langkah 1 sampai dengan langkah 3 cara pengerjaannya sama seperti pada langkah peramalan pada 
metode FTS sehingga untuk langkah 1 sampai dengan langkah 3 pada cara pengerjaan peramalan MFTS dapat dilihat pada metode FTS yang telah dibahas sebelumnya, namun data yang dipergunakan adalah faktor utama (jumlah kunjungan wisatawan Australia) faktor pendukung (inflasi Indonesia dan kurs AUD/IDR).

Untuk Persentase Perubahan Laju inflasi Indonesia dan kurs AUD/IDR Periode Juli 2009 sampai Juni 2014 yang sudah diberikan masing-masing pendekatan diperoleh $\left(E_{1}\right)_{\min }=-17,00 \%$ dan $\left(E_{1}\right)_{\max }=46,00 \%$ dan $\left(E_{2}\right)_{\min }=-5,00 \%$ dan $\left(E_{2}\right)_{\max }=$ $11,00 \%$. Lebar masing-masing intervar adalah 9,00\% dan 2,29\% kemudian membagi masingmasing interval menjadi 7 .

Himpunan fuzzy dan nilai linguistiknya dapat dilihat pada Tabel 3 dan 4

Tabel 3. Interval Fuzzy dan Nilai Lingustik Berdasarkan Distribusi Perubahan Persentase

\begin{tabular}{|c|c|c|c|c|c|}
\hline No & Interval & $\begin{array}{c}\text { Batas } \\
\text { Kiri }\end{array}$ & $\begin{array}{c}\text { Nilai } \\
\text { Tengah }\end{array}$ & $\begin{array}{c}\text { Batas } \\
\text { Kanan }\end{array}$ & $\begin{array}{c}\text { Nilai } \\
\text { Linguistik }\end{array}$ \\
\hline 1 & $B_{1}$ & $-17,00 \%$ & $-12,50 \%$ & $-8,00 \%$ & $b_{1}$ \\
\hline 2 & $B_{, 2}$ & $-8,00 \%$ & $-3,50 \%$ & $1,00 \%$ & $b_{2}$ \\
\hline 3 & $B_{3}$ & $1,00 \%$ & $5,50 \%$ & $10,00 \%$ & $b_{3}$ \\
\hline 4 & $B_{4}$ & $10,00 \%$ & $14,50 \%$ & $19,00 \%$ & $b_{4}$ \\
\hline 5 & $B_{5}$ & $19,00 \%$ & $23,50 \%$ & $28,00 \%$ & $b_{5}$ \\
\hline 6 & $B_{6}$ & $28,00 \%$ & $32,50 \%$ & $37,00 \%$ & $b_{6}$ \\
\hline 7 & $B_{7}$ & $37,00 \%$ & $41,50 \%$ & $46,00 \%$ & $b_{7}$ \\
\hline
\end{tabular}

Tabel 4 Interval Fuzzy dan Nilai Lingustik Berdasarkan Distribusi Perubahan Persentase

\begin{tabular}{|c|c|c|c|c|c|}
\hline No & $\begin{array}{c}\text { Inter } \\
\text { val }\end{array}$ & $\begin{array}{c}\text { Batas } \\
\text { Kiri }\end{array}$ & $\begin{array}{c}\text { Nilai } \\
\text { Tengah }\end{array}$ & $\begin{array}{c}\text { Batas } \\
\text { Kanan }\end{array}$ & $\begin{array}{c}\text { Nilai } \\
\text { Linguistik }\end{array}$ \\
\hline 1 & $C_{1}$ & $-5,00 \%$ & $-3,86 \%$ & $-2,71 \%$ & $c_{1}$ \\
\hline 2 & $C_{2}$ & $-2,71 \%$ & $-1,57 \%$ & $-0,43 \%$ & $c_{2}$ \\
\hline 3 & $C_{3}$ & $-0,43 \%$ & $0,71 \%$ & $1,86 \%$ & $c_{3}$ \\
\hline 4 & $C_{4}$ & $1,86 \%$ & $3,00 \%$ & $4,14 \%$ & $c_{4}$ \\
\hline 5 & $C_{5}$ & $4,14 \%$ & $6,43 \%$ & $8,71 \%$ & $c_{5}$ \\
\hline 6 & $C_{6}$ & $8,71 \%$ & $9,86 \%$ & $11,00 \%$ & $c_{6}$ \\
\hline
\end{tabular}

FLRG pada faktor pendukung dapat dilihat pada tabel 5 dan 6 .

Tabel 5. Distribusi FLRG untuk Inflasi Indonesia

\begin{tabular}{|c|c|c|c|}
\hline $\begin{array}{c}\text { Distribusi } \\
\text { FLRG }\end{array}$ & Frekuensi & $\begin{array}{c}\text { Distribusi } \\
\text { FLRG }\end{array}$ & Frekuensi \\
\hline$B_{1}=>B_{2}$ & 3 & $B_{3}=>B_{5}$ & 1 \\
\hline$B_{1}=>B_{3}$ & 1 & $B_{3}=>B_{7}$ & 1 \\
\hline$B_{1}=>B_{4}$ & 1 & $B_{4}=>B_{2}$ & 1 \\
\hline$B_{2}=>B_{1}$ & 3 & $B_{4}=>B_{3}$ & 2 \\
\hline$B_{2}=>B_{2}$ & 20 & $B_{4}=>B_{4}$ & 2 \\
\hline$B_{2}=>B_{3}$ & 4 & $B_{4}=>B_{6}$ & 1 \\
\hline$B_{2}=>B_{4}$ & 4 & $B_{5}=>B_{3}$ & 1 \\
\hline$B_{3}=>B_{1}$ & 3 & $B_{5}=>B_{5}$ & 1 \\
\hline$B_{3}=>B_{2}$ & 5 & $B_{6}=>B_{3}$ & 1 \\
\hline$B_{3}=>B_{3}$ & 1 & $B_{7}=>B_{3}$ & 1 \\
\hline$B_{3}=>B_{4}$ & 1 & \multicolumn{1}{|c}{} \\
\hline
\end{tabular}

Tabel 6. Distribusi FLRG untuk Inflasi Indonesia

\begin{tabular}{|c|c|c|c|}
\hline $\begin{array}{c}\text { Distribusi } \\
\text { FLRG }\end{array}$ & Frekuensi & $\begin{array}{c}\text { Distribusi } \\
\text { FLRG }\end{array}$ & Frekuensi \\
\hline$C_{1}=>C_{1}$ & 1 & $C_{3}=>C_{3}$ & 14 \\
\hline$C_{1}=>C_{2}$ & 2 & $C_{3}=>C_{4}$ & 4 \\
\hline$C_{1}=>C_{4}$ & 1 & $C_{4}=>C_{3}$ & 7 \\
\hline$C_{2}=>C_{1}$ & 1 & $C_{4}=>C_{4}$ & 2 \\
\hline$C_{2}=>C_{2}$ & 3 & $C_{4}=>C_{5}$ & 1 \\
\hline$C_{2}=>C_{3}$ & 7 & $C_{4}=>C_{6}$ & 1 \\
\hline$C_{2}=>C_{4}$ & 2 & $C_{5}=>C_{6}$ & 1 \\
\hline$C_{3}=>C_{1}$ & 2 & $C_{6}=>C_{4}$ & 1 \\
\hline$C_{3}=>C_{2}$ & 8 & & \\
\hline
\end{tabular}

Hasil fuzzifikasi atau laju persentase dari data faktor utama dan faktor pendukung dibentuk k-faktor dan m-orde dengan persamaan berikut

$$
\begin{aligned}
& \left(X_{j-k} ; Y_{2, j-k} Y_{m-1, j-k}\right), \ldots,\left(X_{j-2} ; Y_{2, j-2}, \ldots, Y_{m-1, j-2}\right), \\
& \left(X_{j-1} ; Y_{1, j-1}, Y_{2, j-1, \ldots .}, Y_{m-1, j-1}\right), \rightarrow X_{j}
\end{aligned}
$$

Langkah selanjutnya hasil peramalan perubahan persentase laju dari faktor utama dan faktor pendukung dikalikan dengan bobot masing-masing, yang diperoleh dengan bantuan softwere problem solving. Berikut model untuk penentuan laju kunjungan 
wisatawan yang akan berkunjung pada bulan berikutnya.

$$
\begin{aligned}
\alpha_{t}^{*}= & \frac{1}{\omega} \cdot\left[\omega_{1} \cdot \alpha_{(1,(t-1))}+\omega_{2} \cdot \alpha_{(2,(t-1))}+\omega_{3} .\right. \\
& \left.\alpha_{(3,(t-1))}+\cdots+\omega_{m} \cdot \alpha_{(m,(t-1))}\right]
\end{aligned}
$$

$\alpha_{t}^{*}=$ Laju perubahan kunjungan wisatawan hasil peramalan

$\omega=$ Total bobot

$\omega_{1}=$ Bobot faktor utama

$\omega_{2}=$ Bobot faktor pendukung pertama

$\omega_{3}=$ Bobot faktor pendukung kedua

$\alpha_{(1,(t-1))}=$ Laju kunjungan wisatawan pada bulan sebelumnya

$\alpha_{(2,(t-1))}=$ Laju perubahan inflasi Indonesia pada bulan sebelumnya

$\alpha_{(3,(t-1))}=$ Laju perubahan kurs AUD/IDR

Kemudian dilakukan tahap Defusifikasi untuk mendapatkan nilai ramalan berdasarkan laju MFTS. Nilai ramalan diperoleh dengan persamaan

$$
\begin{gathered}
\text { data aktual }(t)= \\
{\left[1+\alpha_{t}^{*}\right] \times \text { data sebelumnya }(t-1)}
\end{gathered}
$$

Pada data bulan Juni 2014 jumlah kunjungan wisatawan Australia, inflasi Indonesia, dan kurs AUD/IDR mempunyai nilai perubahan persentase sebesar $8,12 \%$, $8,47 \%$, dan $3,79 \%$ dimana data tersebut masuk ke dalam fuzzy set $A_{5}, B_{1}$ dan $C_{4}$. Pada FLRG $A_{5}, B_{2}$, dan $C_{3}$ yang digunakan untuk meramalkan bulan Juli 2014 karena memiliki masing-masing frekuensi terbanyak. Untuk mencari nilai perubahan persentase pada Juli 2014, maka kita akan menggunakan persentase perubahan defuzzyfikasi, selanjutnya dikalikan dengan masing-masing bobot yang telah ditentukan kemudian ditambah dan dibagi dengan total dari bobot, kemudian dikalikan dengan data bulan Juni 2014. Untuk lebih jelas bisa dilihat pada tabel 7 .

\begin{tabular}{|c|c|c|c|c|}
\hline Bln & $\begin{array}{l}\text { Jumlah } \\
\text { Kunjun } \\
\text { gan } \\
\text { Wisatawan } \\
\text { Australia } \\
\text { (JKWA) }\end{array}$ & $\begin{array}{l}\text { Laju pert } \\
\text { JKWA }\end{array}$ & Fuzzy & $\begin{array}{c}\text { Nilai } \\
\text { Linguistik }\end{array}$ \\
\hline Jun-14 & 86.292 & $8,12 \%$ & \multirow{2}{*}{$\begin{array}{l}A_{5} \\
A_{5}\end{array}$} & 5 \\
\hline Jul-14 & - & - & & 5 \\
\hline Min & Middle & Max & $\begin{array}{c}\text { Defuzzy } \\
\text { fikasi } \\
(\%)\end{array}$ & \\
\hline $1,50 \%$ & $9,93 \%$ & $18,36 \%$ & $4,34 \%$ & \\
\hline $1,50 \%$ & $9,93 \%$ & $18,36 \%$ & $4,34 \%$ & \\
\hline
\end{tabular}

Tabel 7. Nilai Linguistik, Defuzzyfikasi, dan Bobot setiap Faktor untuk Bulan Juni 2014

Tahap berikutnya melakukan peramalan bulan Juli 2014 dengan cara sebagai berikut:

$\operatorname{DataAktual}(t)=\left[1+\alpha_{t}^{*}\right] \times$ Data Sebelumnya $(t-1)$

$$
\begin{gathered}
=\left[1+\left(\frac{((4,34 \% \times 0,999)+(-8,52 \% \times-0,090)+(1,60 \% \times 0,021))}{0,999+(-0,90)+0,021}\right)\right] \times 86.292 \\
=\left[1+\left(\frac{5,13 \%}{0,930 \%}\right)\right] \times 86.292 \\
=6,52 \% \times 86.292 \\
=91.059 \text { jiwa }
\end{gathered}
$$

Tahap selanjutnya adalah membandingkan nilai AFER dari metode FTS dengan metode MFTS untuk mengetahui metode mana yang lebih akurat digunakan dalam meramalkan jumlah kunjungan wisatawan Australia ke Bali. Perbandingan bisa dilihat pada Tabel 8 .

Tabel 8. Perbandingan nilai AFER dari Data out-sample

\begin{tabular}{|c|c|}
\hline Metode & AFER \\
\hline FTS & $4,83 \%$ \\
\hline MFTS & $3,75 \%$ \\
\hline
\end{tabular}

Berdasarkan Tabel 8 dapat dilihat bahwa nilai AFER dari metode MFTS lebih kecil dari metode FTS sehingga terdapat peningkatan akurasi peramalan menggunakan metode MFTS sebesar 1,08 persen terhadap metode FTS. Jadi peramalan jumlah kunjungan wisatawan Australia ke Bali lebih baik menggunakan metode MFTS dari pada metode FTS. 


\section{SIMPULAN DAN SARAN}

Berdasarkan hasil dan pembahasan, dapat disimpulkan bahwa Peramalan jumlah kunjungan wisatawan Australia ke Bali lebih baik menggunakan metode MFTS dari pada metode FTS. Kemudian hasil peramalan menggunakan metode MFTS diperoleh jumlah wisatawan Australia yang akan berkunjung ke Bali pada Juli 2014 sebanyak 91.056 jiwa.

Saran yang dapat disampaikan untuk penelitian selanjutnya adalah pemilihan untuk faktor pendukung pada metode Multivariate Fuzzy Time Series agar lebih selektif dan sangat berpengaruh tehadap faktor utama, karena faktor pendukung sangat berpengaruh terhadap tingkat peramalan.

\section{DAFTAR PUSTAKA}

[1] Dispar Provinsi Bali. 2014. Bali Government Tourism Office. Dipetik September 2014, 30, dari www.disparda.baliprov.go.id

[2] Wamayasa,A., I.P. Eka N. Kencana, \& Nilakusmawati, $\quad$ D.P.E. 2012. Peramalan Produk Domestik Regional Bruto (PDRB) Provinsi Bali dengan Menggunakan Metode Fuzzy Time Series. e-Jurnal Matematika, I(1), 1219.

[3] Abadi, A. M., Subanar, Widodo, \& Saleh, S. 2010. Peramalan Tingkat Suku Bunga Sertifikat Bank Indonesia. Jurnal ILMU DASAR, XI(2), 205-211.

[4] Jilani, T. A., Burney, S. A., \& Ardil, C. 2008. Multivariat High Order Fuzzy Time Series Forecasting for Car Road Accidents. World Academy of Science, Engineering and Technology International Journal of Computer, Information, Systems and Control Engineering, VI, 44-49

[5] Makridakis, S., Wheelwright, S. C., \& McGee, V. E. 1999. Metode dan Aplikasi Peramalan (2nd ed.). Tangerang: Binarupa Aksara.
[6] Stevenson, M., \& Porter, J. E. 2009. Fuzzy Time Series Forcasting Using Percentage Change as the Universe Discourse. World Academy of Science, Engineering and Technology, 3, 145-148.

[7] Sturges, H. A. 1926. The Choice of a Class Interval. Journal of the American Statistical Association(21), 65-66. 